\title{
English Plantain Pollen IgA Measurement
}

National Cancer Institute

\section{Source}

National Cancer Institute. English Plantain Pollen IgA Measurement. NCI Thesaurus.

Code C130085.

A measurement of the English plantain (Plantago lanceolata) pollen IgA in a biological specimen. 